\title{
Cytochemical responses of the lysosomal system and NADPH-ferrihemoprotein reductase in molluscan digestive cells to environmental and experimental exposure to xenobiotics
}

\author{
M. N. Moore \\ Plymouth Marine Laboratory (West Hoe), Prospect Place, The Hoe, Plymouth PL1 3DH, United Kingdom
}

\begin{abstract}
Lysosomal characteristics and smooth endoplasmic reticulum (SER) associated NADPHferrihemoprotein (cytochrome P-450) reductase were measured cytochemically in the digestive cells of mussels Mytilus edulis and periwinkles Littorina littorea exposed to environmental contaminants in Langesundfjord, Norway (PAHs, PCBs, metals) and to xenobiotics in an experimental facility (diesel oil and copper mixture). Lysosomal membrane stability was reduced in both mussels and periwinkles with increasing xenobiotic contamination in the field. Lysosomal and cytoplasmic unsaturated neutral lipid concentration was increased in contaminated mussels in the field, and lysosomal accumulation was associated with enlargement of secondary lysosomes; the latter was inversely correlated with lysosomal membrane stability. Lipofuscin content and number of tertiary lysosomes increased in contaminated field mussels. These pathological changes are indicative of enhanced lysosomal autophagy and fatty degeneration. NADPH-ferrihemoprotein reductase activity was elevated in mussels from the 2 most heavily contaminated field sites. Activity of this enzyme was directly correlated with total PAHs. Lysosomal data from experimental exposures were less clear and difficult to interpret. Poor nutritional conditions possibly masked pollutant effects. However, mussels from the highest exposure concentration showed elevated lipofuscin. The observed sensitivity of the tests for lysosomal enlargement and lysosomal lipid, combined with their relative simplicity, indicate their potential for the detection of environmentally induced pathology, although better understanding of the mechanisms of toxicity would enhance their utility.
\end{abstract}

\section{INTRODUCTION}

Digestive cells of the molluscan digestive gland have a highly developed lysosomal system which is involved in intracellular digestion of endocytosed food (Owen 1972). This lysosomal system is sensitive to environmental perturbations including many pollutants, and several indices of detrimental biological effect have been based on the responses of lysosomes in the digestive cells (review by Moore 1985). Lysosomal responses can be grouped into 3 classes: changes in fusion events, changes in lysosomal components, and changes in membrane permeability (Hawkins 1980). In the molluscan digestive cell, lysosomal alterations have been described that involve all of these categories of response. Increased fusion and lysosomal enlargement occur in cells undergoing pathological degenerative processes, while increases in the content of hydrolytic enzymes, lipofuscin and neutral lipid are associated with exposure to xenobiotics such as polycyclic aromatic hydrocarbons (Lowe et al. 1981, Moore \& Clarke 1982, Moore et al. 1982, 1985, 1986, 1987). Increases in permeability of lysosomal membranes is perhaps the best documented response, being associated with a wide range of environmental stimuli and apparently leading to enhanced protein catabolism and cellular atrophy (Lowe et al. 1981, Moore 1985, Moore \& Viarengo 1987 ).

NADPH-ferrihemoprotein reductase (EC 1.6.2.4), formally known as NADPH-cytochrome c (P-450 or neotetrazolium) reductase, is a flavoprotein involved in the electron transfer system of the endoplasmic reticulum (Masters \& Okita 1980, Strobel et al. 1980). The reductase activity can be determined biochemi- 
cally using a variety of electron acceptors and cytochemically using tetrazolium salts, such as neotetrazolium, in the absence of intermediate electron acceptors (e.g. menadione), with subsequent quantitation of reaction product using microdensitometry (Altman 1972, Moore 1979, 1985, Van Noorden \& Butcher 1986). This enzyme is apparently induced by a number of organic xenobiotics including certain PAHs (review by Moore 1985).

The objective of the present study was to test responses of the above systems in both an environmental and an experimental situation. Mytilus edulis and Littorina littorea were sampled from a contaminant gradient in Langesundfjord and from the experimental facility at Solbergstrand where these molluscs were exposed to different concentrations of a mixture of diesel oil and copper (Abdullah \& Steffenak 1988, Klungsøyr et al. 1988). The responses of the lysosomal system in digestive cells of mussels and periwinkles were examined. Lysosomal membrane stability (permeability) was tested in both species; in mussels, additional tests were carried out for evidence of lysosomal swelling or enlargement, as well as lipofuscin and neutral lipid content. NADPH-ferrihemoprotein reductase activity was also determined in the digestive cells of mussels.

\section{MATERIAL AND METHODS}

Collection and experimental facility. Mytilus edulis (4 to $6 \mathrm{~cm}$ shell length) and Littorina littorea ( 2 to $2.5 \mathrm{~cm}$ shell height) were collected from Field sites 1 to 4 along the contaminant gradient in Langesundfjord, and from control (C), low (L), medium (M) and high (H) exposure treatments, as well as a second control for the highexposure molluscs $(\mathrm{CH})$, in the exposure experiment at Solbergstrand. Full details of sites, animal collection and experimental exposures are given by Bakke et al. (1988) and Follum \& Moe (1988)

Concentrations of pollutants in the experimental basins were, $\mathrm{C}: 3.0 \pm 0.7 \mathrm{ppb}$ hydrocarbons (fluorescence analysis), L: $6.4 \pm 1.8$ ppb hydrocarbons and 0.8 $\mathrm{ppb} \mathrm{Cu}, \mathrm{M}: 31.5 \pm 22.3 \mathrm{ppb}$ hydrocarbons and $5 \mathrm{ppb}$ $\mathrm{Cu}, \mathrm{H}: 124.5 \pm 65.3 \mathrm{ppb}$ hydrocarbons and $20 \mathrm{ppb} \mathrm{Cu}$ (hydrocarbon values are mean $\pm \mathrm{SD}$ over the dosing period, $\mathrm{Cu}$ values are nominal levels). Molluscs were exposed for ca $15 \mathrm{wk}$, with the exception of $\mathrm{H}$ mussels and their control (CH), which were exposed for $25 \mathrm{~d}$ only, due to high mortality during the longer treatment period.

Tissue preparation for cytochemistry. Digestive glands were dissected from mussels and periwinkles ( $n$ $=10$ ind per condition) on their arrival in the laboratory. Small pieces of digestive gland (ca $5 \times 5 \times 5 \mathrm{~mm}$ ) were placed on aluminium cryostat chucks, with 5 pieces of tissue in a straight row across the centre. The chuck was then placed for $1 \mathrm{~min}$ in a small bath of hexane (aromatic hydrocarbon-free; boiling range 67 to $70^{\circ} \mathrm{C}$ ), which had been precooled to $-70^{\circ} \mathrm{C}$ in liquid nitrogen in order to quench the tissue. The chuck plus the quenched solidified tissues were then sealed by doubly-wrapping in 'Parafilm' and stored at $-30^{\circ} \mathrm{C}$ until required for sectioning. Tissue sections (10 um thick) were prepared in a Bright's cryostat (motorised cutting speed setting 50 ) with a cabinet temperature of less than $-25^{\circ} \mathrm{C}$. The knife was cooled by surrounding the haft with solid $\mathrm{CO}_{2}$. Sections were transferred to slides at room temperature, which effectively flashdried them (Bitensky et al. 1973); the sections were stored in the cryostat until required, but for not longer than $4 \mathrm{~h}$.

Assessment of lysosomal membrane stability. Determination of lysosomal stability was based on acid labilization characteristics of latent hydrolases, in the responsive primary fraction of latent enzyme in digestive cells, as previously described by Moore (1976). The acid hydrolases used in this study included $\beta-N$ acetylhexosaminidase (EC 3.2.1.52) in mussels and $\beta$-glucuronidase (EC 3.2.1.31) in periwinkles.

$\beta$-N-Acetylhexosaminidase. Serial cryostat sections, prepared as described above, were subjected to acid labilization at $37^{\circ} \mathrm{C}$ in $0.1 \mathrm{M}$ citrate buffer ( $\mathrm{pH} 4.5$ ) containing $2.5 \% \mathrm{NaCl}(\mathrm{w}: \mathrm{v})$. The acid labilization sequence involved treating serial sections for $0,2,5,10$, $15,20,25,30$ and $35 \mathrm{~min}$ respectively. Following this treatment sections were transferred to the substrate incubation medium consisting of $20 \mathrm{mg}$ naphthol ASBI-N-acetyl- $\beta$-D glucosaminide (Sigma) dissolved in $2.5 \mathrm{ml} \mathrm{2-methoxyethanol,} \mathrm{and} \mathrm{made} \mathrm{up} \mathrm{to} 50 \mathrm{ml}$ with $0.1 M$ citrate buffer ( $\mathrm{pH} 4.5$ ) containing $2.5 \% \mathrm{NaCl}$ ( $w: v$ ) and $3.5 \mathrm{~g}$ of low viscosity polypeptide (Sigma POLYPEP P5115) to act as a section stabiliser. Sections were incubated in this medium for $15 \mathrm{~min}$ at $37^{\circ} \mathrm{C}$, rinsed in $3.0 \% \mathrm{NaCl}$ at $37^{\circ} \mathrm{C}$ for $2 \mathrm{~min}$ and then transferred to $0.1 \mathrm{M}$ phosphate buffer ( $\mathrm{pH} 7.4$ ) containing fast violet $\mathrm{B}$ ( $1 \mathrm{mg} \mathrm{m}$ ! ' $)$, at room temperature for 10 min. Slides were then rinsed in running tap water for 5 min, fixed for 15 min in calcium-formal at $4{ }^{\circ} \mathrm{C}$, rinsed in distilled water and cover glasses were mounted using aqueous mounting medium (Difco UV-free).

$\beta$-Glucuronidase. The method for visualization of $\beta$ glucuronidase was similar to that above, but with the following exceptions: the acid labilizing treatment was carried out in $0.1 \mathrm{M}$ acetate buffer ( $\mathrm{pH} 4.5$ ) containing $2.5 \% \mathrm{NaCl}(\mathrm{w}: \mathrm{v}$ ), and the substrate incubation used $1.4 \mathrm{mg}$ naphthol AS-BI- $\beta$-D-glucuronide (Sigma) as substrate, dissolved in $0.5 \mathrm{ml}$ dimethylformamide, made up to $50 \mathrm{ml}$ with $0.1 \mathrm{M}$ acetate buffer ( $\mathrm{pH} 4.5$ ) containing $2.5 \% \mathrm{NaCl}(\mathrm{w} \cdot \mathrm{v}$ ) and $3.5 \mathrm{~g}$ of polypeptide. Sections were incubated for 15 min at $37^{\circ} \mathrm{C}$. 
Determination of lysosomal labilization period. The labilization period is the time of acid labilization required to fully labilize the responsive fraction of lysosomal hydrolase in the digestive cells. This was assessed microscopically as the first peak or maximum of reaction product associated with the lysosomes, as related to increasing time of acid labilization (Moore 1976, Moore et al. 1978). Four determinations were made for each animal by dividing each section in the acid labilization sequence into 4 approximately equal segments and assessing the labilization period in each of the corresponding set of segments. A mean value was then derived for each section, corresponding to an individual digestive gland.

Pathological enlargement of lysosomes. Evidence of pathological lysosomal enlargement was determined by microscopical assessment of the digestive cells in sections of mussel digestive gland reacted for $\beta-N$ acetylhexosaminidase. The presence of a few enlarged lysosomes was not considered to be abnormal and a section was only considered to represent a pathological condition if the majority of digestive tubules showed evidence of uniform lysosomal enlargement.

Determination of unsaturated neutral lipid. Duplicate cryostat sections $(10 \mu \mathrm{m})$ were post-fixed in calcium-formal for $15 \mathrm{~min}$ at $4{ }^{\circ} \mathrm{C}$, then rinsed in distilled water and placed in $60 \%$ triethylphosphate in distilled water for $3 \mathrm{~min}$. Sections were stained in a $1 \%$ solution of oil red 0 in $60 \%$ triethylphosphate at $20^{\circ} \mathrm{C}$ for 15 min (Bancroft 1967), then washed in $60 \%$ triethylphosphate for $30 \mathrm{~s}$, rinsed in distilled water and mounted in UV-free aqueous mounting medium. Lipid content of digestive cells was determined using a Vickers M85 scanning integrating microdensitometer at $530 \mathrm{~nm}$, with a measuring beam diameter of $0.5 \mu \mathrm{m}$ and a mask area of $130 \mathrm{\mu m}^{2}$. A total of 10 readings was made on each of 2 duplicate sections (i.e. 20 readings per mollusc sampled).

Determination of lipofuscin. Lipofuscin content of tertiary lysosomes was detected using the Schmorl reaction (Pearse 1972). Duplicate cryostat sections (10 um) were fixed for $15 \mathrm{~min}$ in calcium-formal at $4{ }^{\circ} \mathrm{C}$. Sections were then rinsed in distilled water and immersed in the reaction medium. This latter contained $1 \%$ ferric chloride and $1 \%$ potassium ferricyanide in a ratio of $3: 1$. Sections were stained for $5 \mathrm{~min}$ in this solution then rinsed in $1 \%$ acetic acid for $1 \mathrm{~min}$, followed by rinsing in distilled water and mounting in aqueous mounting medium. The blue reaction product indicating lipofuscin was measured microdensitometrically as for lipid, at a wavelength of $660 \mathrm{~nm}$.

Determination of NADPH-ferrihemoprotein reductase activity. NADPH-ferrihemoprotein (neotetrazolium) reductase activity was localized in duplicate cryostat sections $(10 \mu \mathrm{m})$, as described by Moore (1979).
The method used 0.1 MHEPES buffer ( $\mathrm{pH} 8.0$ ) containing $20 \mathrm{mM} \mathrm{MgCl} 2,20 \%$ polyvinyl alcohol (Sigma P8136 Type II, MW about 12 000), $6 \mathrm{mMNADPH}$ and 5 $\mathrm{m} M$ neotetrazolium chloride (Sigma). This medium was purged with $\mathrm{O}_{2}$-free nitrogen for several minutes, and sections were incubated in darkness for $30 \mathrm{~min}$ at $37^{\circ} \mathrm{C}$ in a nitrogen atmosphere, in an enclosed container kept moist by a bottom lining of damp tissue paper. The incubation medium was placed on sections surrounded by rubber formers. The sections were washed in running water, rinsed in distilled water and mounted in aqueous medium. Reaction products (blue and red formazans) were measured at the isobestic wavelength of $585 \mathrm{~nm}$ (Butcher \& Altman 1973), using a Vickers M85 microdensitometer as described above.

Statistical treatment of data. Data were compared using Mann-Whitney $U$-tests. $\chi^{2}$-tests and Fisher exact probability tests were used for comparison of incidences of lysosomal enlargement.

\section{RESULTS}

Contaminant concentrations in Mytilus edulis and Littorina littorea were analysed for both field sites and experimental exposures by Abdullah \& Steffenak (1988) and Klungsøyr et al. (1988). In summary, these showed an increase in whole-mussel tissue concentrations through Field sites 1 to 4 for both PAHs (respectively $2240 \pm 80,5870 \pm 130,11460 \pm 600$ and $15470 \pm 1430 \mathrm{ng} \mathrm{g}^{-1}$ dry wt, mean \pm semi-range, $n=$ 2) and PCBs $(77 \pm 7,180 \pm 10,225 \pm 15$ and $275 \pm 25$ ng $\mathrm{g}^{-1}$ dry wt, mean \pm semi-range, $n=2$ ); concentrations of trace metals showed less evidence of change (Appendix 1). For experimental exposures, PAH concentrations in whole-mussel tissue were C: $1080 \pm 90$, $\mathrm{CH}: 620 \pm 30, \mathrm{~L}: 6200 \pm 180, \mathrm{M}: 22740 \pm 250$ and $\mathrm{H}$ : $8190 \pm 860 \mathrm{ng} \mathrm{g}^{-1}$ dry wt (mean \pm semi-range, $n=2$ ); copper concentrations were $\mathrm{C}: 7.3, \mathrm{CH}: 6.6, \mathrm{~L}: 16.3, \mathrm{M}$ : 26.8 and $\mathrm{H}: 59.0 \mu \mathrm{g} \mathrm{g}^{-1}$ dry wt.

\section{Field sites: mussels}

The lysosomal system of digestive cells showed extensive evidence of abnormality in samples from Sites 2, 3 and 4, compared with those from Site 1. Assessment of lysosomal characteristics included lysosomal enlargement, membrane stability, unsaturated neutral lipid and lipofuscin content; results are summarised in Fig. 1. These findings clearly demonstrate that secondary lysosomes were enlarged in molluscs from Sites 2 and 3 , and to a lesser extent (though not significantly) at Site 4 (Figs. 1 \& 2) Lysosomal membrane stability was significantly 

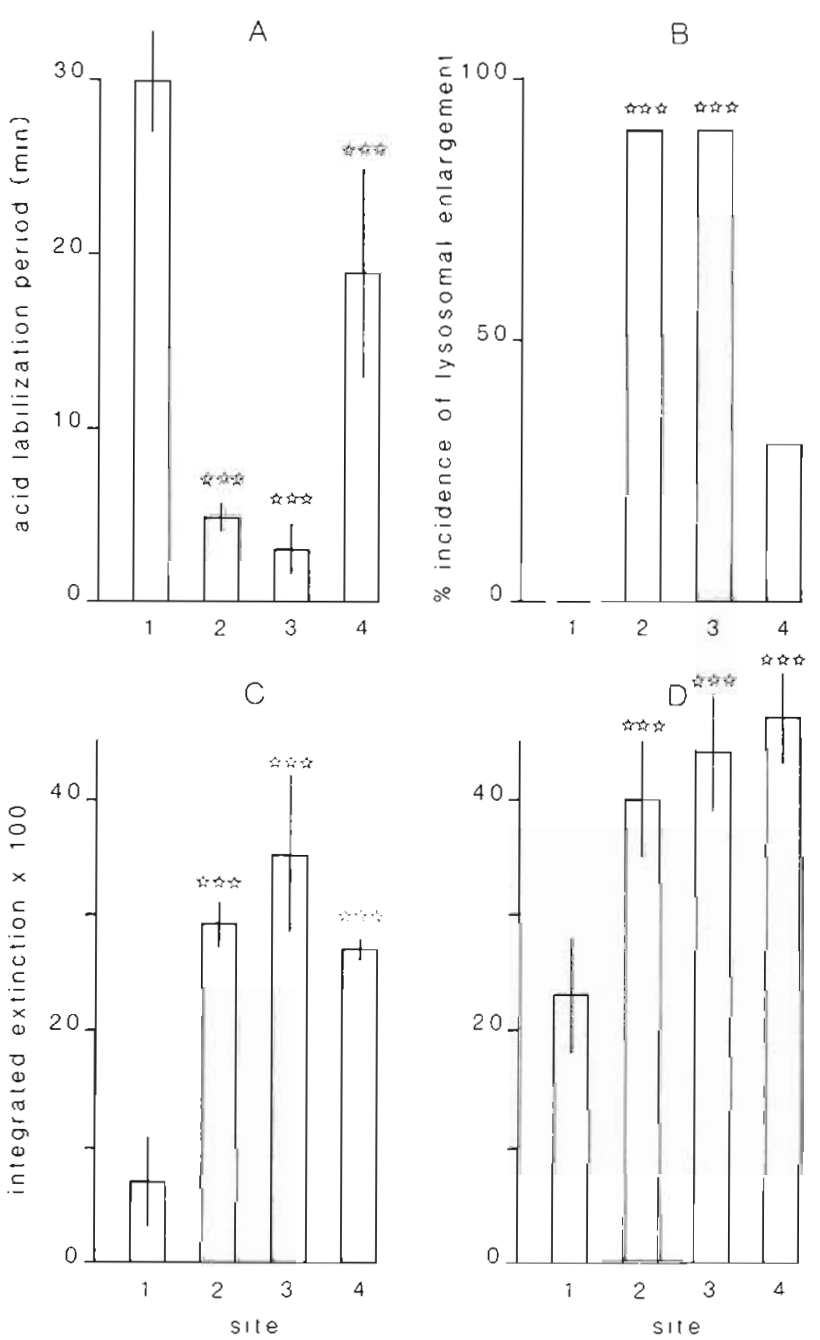

Fig. 1. Mytilus edulis. Responses of lysosomes in digestive cells of mussels from Field sites 1 to 4 in Langesundfjord (mean $\pm 95 \% \mathrm{CI}$, mean only for (B]). (A) Lysosomal membrane stability; (B) incidence of lysosomal enlargement; (C) cytoplasmic content of unsaturated neutral lipid (measured as integrated extinction); (D) lysosomal content of lipofuscin (measured as integrated extinction). Difference from the reference site (1) indicated by $p<0.001$

reduced in mussels from Sites 2, 3 and 4 in comparison with those from Site 1; Site 4 showed considerable variability (Fig. 1) and its mean value was significantly above that for Sites 2 and $3(p<0.01)$, indicating less severe membrane disturbance. Data for lysosomal stability were inversely correlated with those for incidence of lysosomal enlargement $(r=-0.994$, df $=2, p<0.01$; Fig. 3).

Increased amounts of unsaturated neutral lipid were frequently associated with enlarged secondary lysosomes, in addition to being present as lipid droplets, in samples from Sites 2, 3 and $4 ;$ this abnormality apparently constituted a form of fatty degeneration. and increased cellular lipid content was confirmed by microdensitometric measurements (Fig. 1). This latter determination included both cytoplasmic lipid droplets and lysosomally associated lipid (Fig, 2).

Digestive cells generally contain tertiary lysosomes or residual bodies; these are characterised by the presence of lipofuscin detectable as a positive Schmorl reaction. Microdensitometric determination clearly demonstrated significant increases in lipofuscin content in cells from Sites 2, 3 and 4 in comparison with those from Site 1 (Fig. 1). Microscopic assessment of digestive cells revealed an increase in numbers of residual bodies at those sites showing enhanced lipofuscin content (Fig. 2).

NADPH-ferrihemoprotein reductase activity was present in digestive cells of mussels from all 4 sites; however, the amount of formazan reaction product was significantly higher at Sites 3 and 4 in comparison with Sites 1 and 2 (Fig. 4). In addition, mean values for this enzyme showed a positive linear relation to total $\mathrm{PAH}$ concentrations ( $r=0.986$, df $=2, p<0.02$; Fig. 5).

\section{Field sites: periwinkles}

Lysosomal membrane stability was determined in digestive cells of periwinkles; findings are illustrated in Fig. 6. They demonstrate that lysosomal membrane stability was significantly reduced at Sites 2,3 and 4 in comparison with Site 1.

\section{Experimental exposures: mussels}

Results for lysosomal enlargement, membrane stability, unsaturated neutral lipid and lipofuscin content are summarised in Fig. 7 There was extensive enlargement of secondary lysosomes in all treatments except the low exposure condition; lysosomal membrane stability was also depressed in all treatments except the low exposure condition. As in the molluscs from the field site, unsaturated neutral lipid was associated with lysosomal enlargement, in addition to being present as lipid droplets; cellular content of lipid was similar for all experimental conditions. Lipofuscin content associated with tertiary lysosomes was significantly elevated in the high exposure condition in comparison with the $\mathrm{CH}$ control (Fig. 7).

\section{Experimental exposures: periwinkles}

Determinations of lysosomal membrane stability in digestive cells of periwinkles are summarised in Fig. 8 These show that membrane stability was greater in the sample from the medium exposure condition than in 

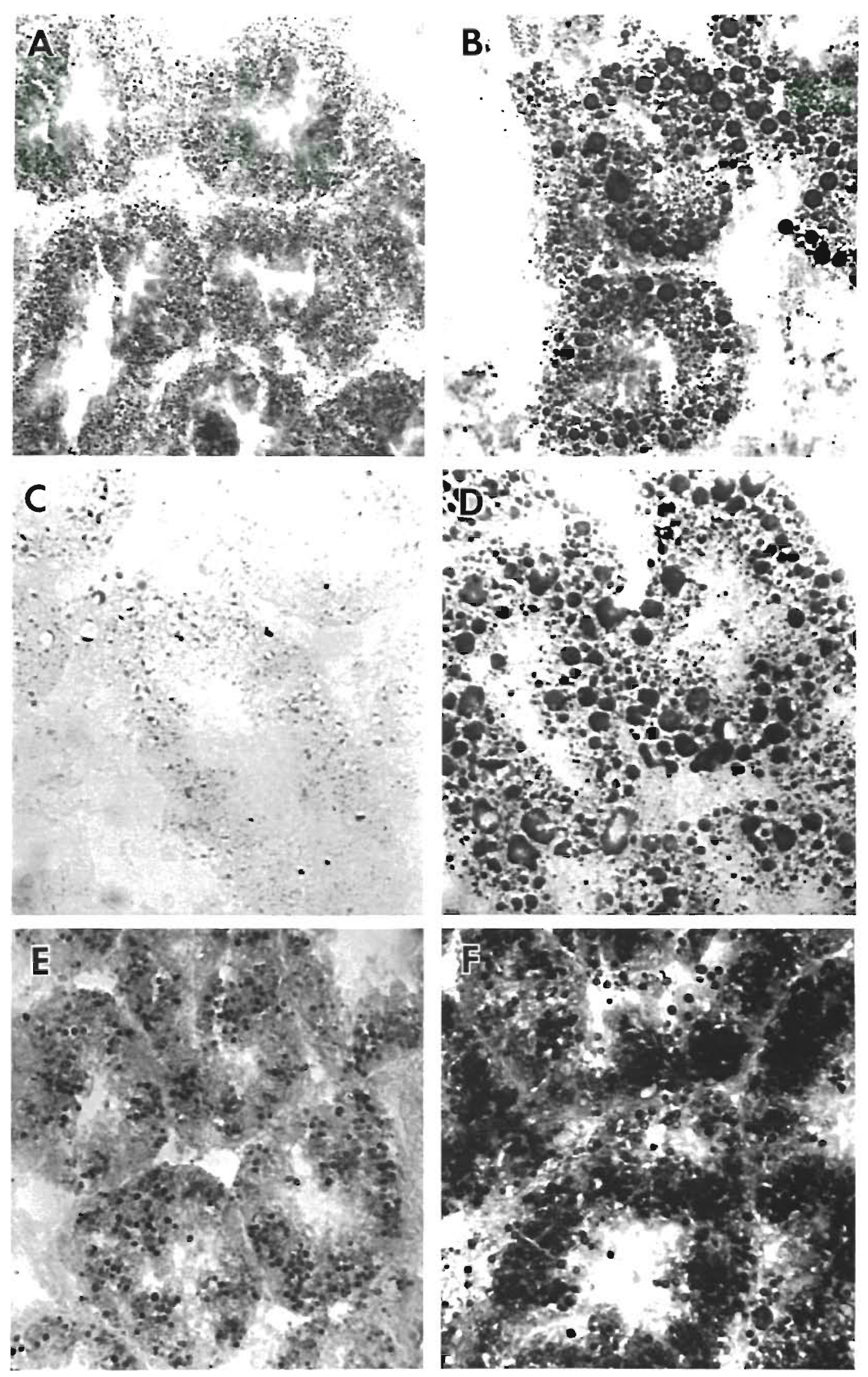

Fig. 2. Mytilus edulis. Cryostat tissue sections $(\times 400)$ through digestive tubules showing: (A) normal appearance of lysosomes reacted for $\beta-\mathrm{N}$-acetylhexosaminidase mainly in digestive cells (Site 1); (B) abnormally enlarged lysosomes reacted for $\beta$ - $N$ acetylhexosaminidase (Site 3); (C) lipid droplets localized in digestive cells using oil red 0 (Site 1); (D) unsaturated neutral lipid accumulation in pathologically enlarged lysosomes, together with a general increase in lipid droplets (Site 3): (E) lipofuscin in

secondary and tertiary lysosomes localized using the Schmorl reaction (Site 1), (F) enhanced lipofuscin content (Site 3) 


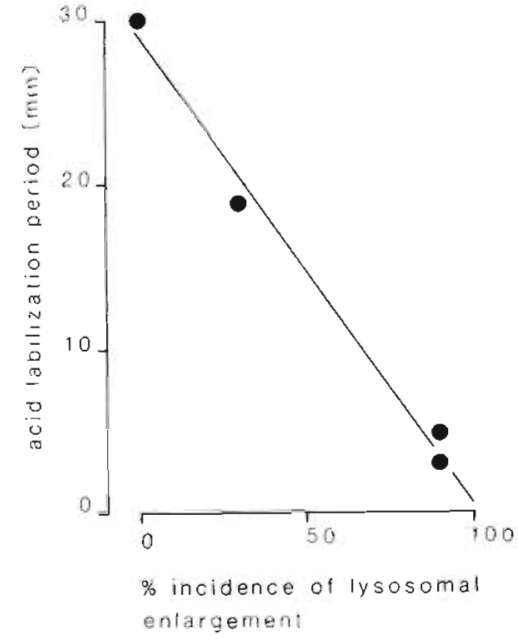

Fig. 3. Mytilus edulis. Relation between lysosomal membrane stability and incidence of lysosomal enlargemert in mussels from field sites

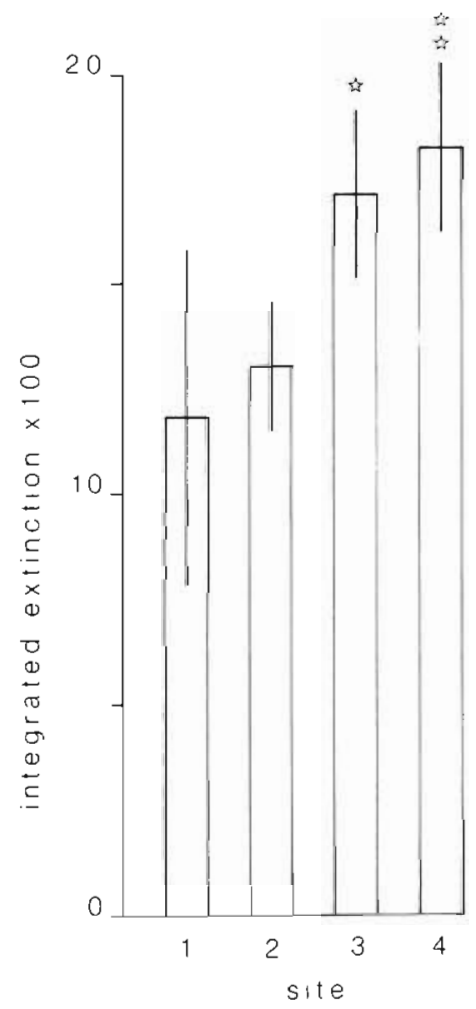

Fig. 4. Mytilus edulis. Responses of NADPH-ferrhemoprotein reductase (mean $\pm 95 \% \mathrm{CI}$ ) in digestive cells of mussels from Field sites 1 to 4 . Difference from reference site indicated by $p<0.05, \quad p<0.01$

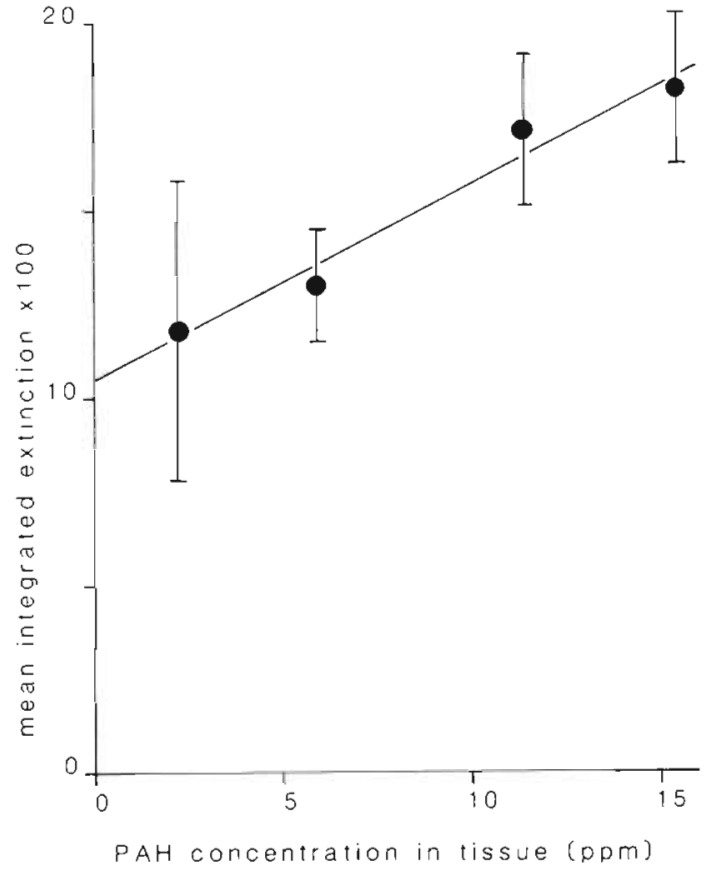

Fig. 5. Mytilus edulis. Relation between NADPH-ferrihemoprotein reductase activity (mean $\pm 95 \% \mathrm{CI}$ ) in digestive cells and concentration of PAHs in mussel tissues from Field sites 1 to 4

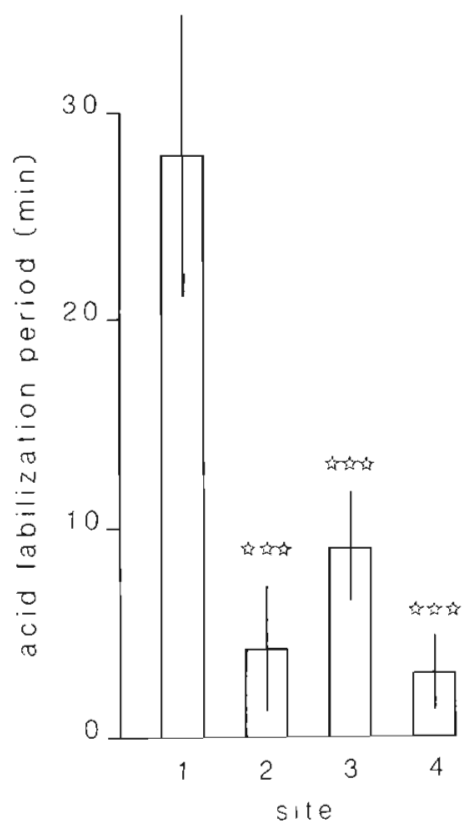

Fig. 6. Littorina littored. Responses of lysosomal membrane stablity (mean $\pm 95 \% \mathrm{Cl}$ ) in digestive cells of periwinkles from Field sites 1 to 4 . Difference from reference site indicated by $\quad p<0.001$ 

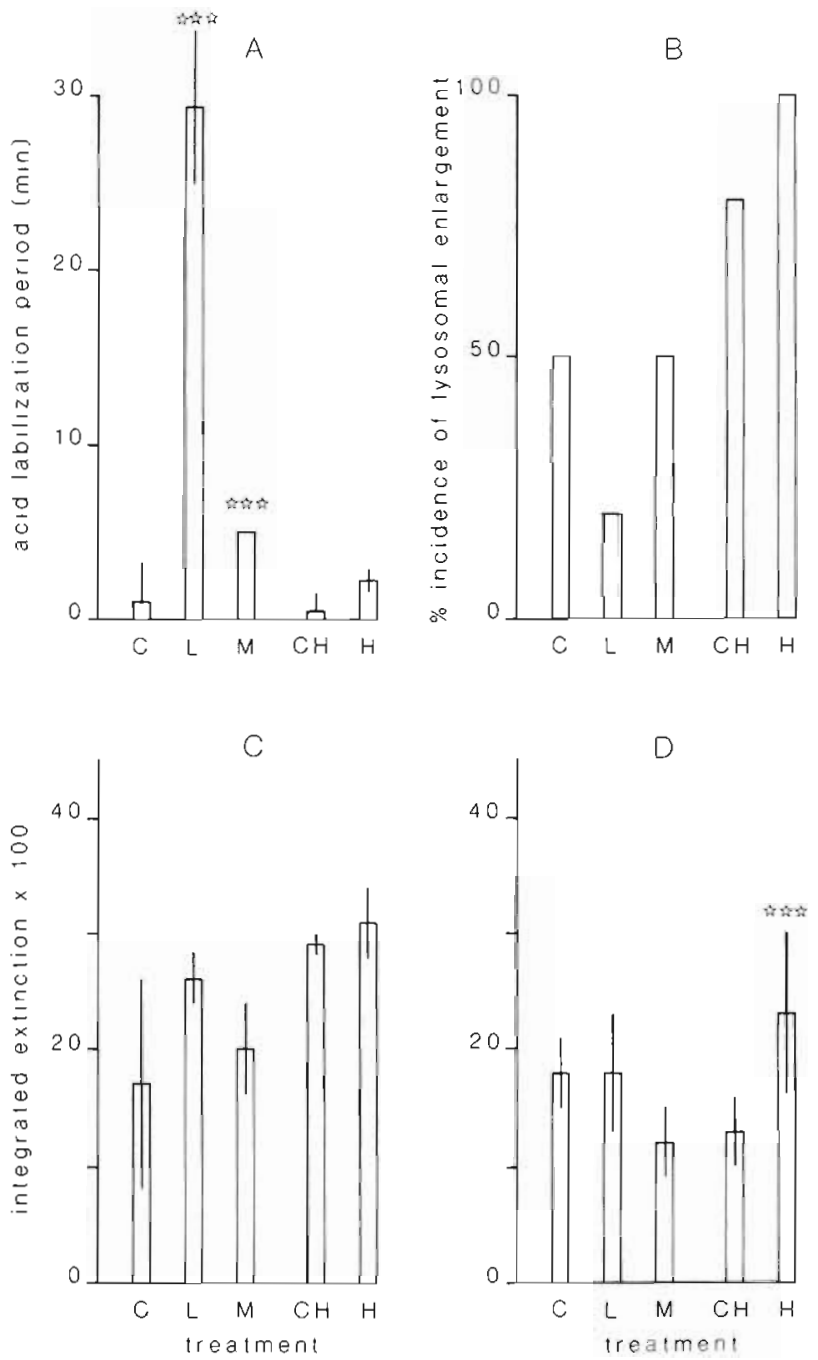

Fig. 7. Mytilus edulis. Responses of lysosomes in digestive cells of mussels from experimental exposures $\mathrm{C}, \mathrm{L}, \mathrm{M}, \mathrm{CH}$ and $\mathrm{H}$ (mean $\pm 95 \% \mathrm{Cl}_{1}$ mean only for $\left.[\mathrm{B}]\right)$. (A) Lysosomal membrane stability; (B) incidence of lysosomal enlargement; (C) cytoplasmic content of unsaturated neutral lipid (integrated extinction): (D) lysosomal content of lipofuscin (integrated extinction). Difference from control basin ( $\mathrm{C}$ or $\mathrm{CH}$ ) indicated by $p<0.001$

any of the other experimental conditions, which were consistently low. These data cannot be satisfactorily explained.

\section{DISCUSSION}

The results demonstrate that the lysosomal system in digestive cells of Mytilus edulis and Littorina littorea is involved in pathological changes occurring in individuals exposed to environmental pollutants, which here include polycyclic aromatic hydrocarbons (PAHs) and

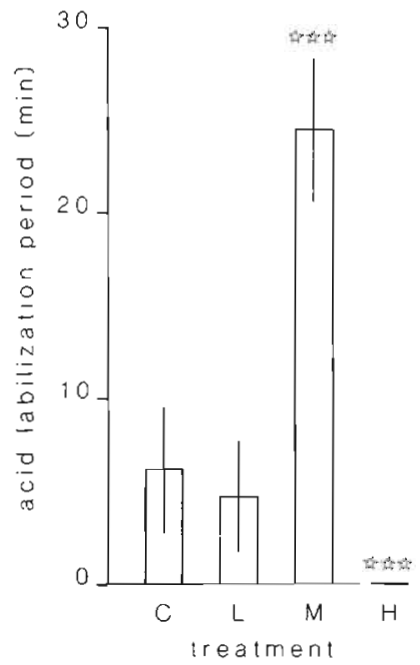

Fig. 8. Littorina littorea. Responses of lysosomal membrane stability (mean $\pm 95 \% \mathrm{CI}$ ) in digestive cells of periwinkles from $C, L, M$, and $H$. Difference from control basin (C) indicated by $p<0.001$

polychlorinated biphenyls (PCBs). Similar pathological changes have been described in both mussels and periwinkles following experimental exposure to PAHs, both in the laboratory and in large mesocosms (Moore 1979, 1985, Moore et al. 1985, Livingstone et al. 1986). Further support comes from previous field investigations where evidence of lysosomal dysfunction has been reported (Moore et al. 1982, Moore 1985, Moore et al. 1986).

Evidence for reduced severity of lysosomal pathology in mussels from Field Site 4 - the most impacted site in terms of PAHs and PCBs - may be suggestive of possible selection for more tolerant or resistant types at this location. Obviously the present sample size is too small to reach any conclusions in this respect; however, the mussels at this site could well merit further study.

Unlike the data from the field sites in Langesundfjord, the results of experimental exposure to diesel oil and copper are more difficult to interpret. In mussels, all samples showed evidence of lysosomally associated fatty degeneration, with a significant increase in lipofuscin in the high exposure animals. Lysosomal membrane stability, however, was greatest in the lowexposure individuals. The food level available to mussels in the experimental exposures was low and this may have contributed to the pathological effects observed in all samples (Widdows \& Johnson 1988). In this context, starvation in periwinkles is known to result in abnormal enlargement of the lysosomes (Moore et al. 1986). Certain xenobiotics exert biphasic effects and it is conceivable that the concentration of PAHs present in the low-exposure individuals may have induced a stabilising effect on the lysosomal 
membranes, resulting in a marked increase in membrane stability over the control value (Szego 1975, Stebbing 1981).

The observed increase in activity of NADPHferrihemoprotein reductase in digestive cells of mussels from the 2 field sites with the greatest tissue concentrations of organic pollutants is entirely consistent with previous data for this enzyme, both from field and experimental investigations (Moore 1979, Moore et al. 1982, 1986, Livingstone et al. 1986, Nott \& Moore 1987). However, biochemical determinations of the activity of this enzyme (measured as NADPH-cytochrome c reductase; Livingstone 1988) are not in agreement with the cytochemical evidence. There is no immediate explanation for this apparent discrepancy, as previous investigations have generally shown good agreement (Livingstone et al. 1986). However, as the cytochemical test for this enzyme is performed on the cells in situ (i.e. cryostat tissue sections), the possibility of disruptive membrane disturbances resulting from tissue homogenization and preparation of microsomes is eliminated.

A general feature of the results is that fatty degeneration and the associated lysosomal accumulation of unsaturated neutral lipid is a useful indicator of pathological alteration in digestive cells of mussels. Support for this statement derives from the evidence that such enlarged and lipid-enriched lysosomes frequently showed reduced membrane stability, which is indicative of their increased fragility. These parameters were in fact inversely correlated for the field data and, also, inversely correlated for the combined field and experimental data $(r=-0.858$, df $=7, p<0.01)$. This Iysosomal accumulation of neutral lipid appears to be a novel observation in bivalve molluscs and could be described as a chemically-induced lipidosis (Dianzani 1978, Lüllmann-Rauch 1979). The cytochemical evidence is consistent with an increase in cytoplasmic lipid content, probably in the form of lipid droplets, and transference of part of this lipid to the lysosomal compartment by autophagic uptake. This phenomenon is indicative of either increased synthesis or decreased utilization of neutral lipid, leading to enhanced autophagy of the accumulated lipid in the digestive cells. This is in keeping with other evidence for augmented autophagy being associated with reduced lysosomal membrane stability, probably involving an increase of fluidity of the lysosomal membranes (Pipe \& Moore 1985, Storch \& Kleinfeld 1985, Moore \& Viarengo 1987).

Lipofuscin build-up in digestive cells of mussels showing other evidences of lysosomal pathology is consistent with enhanced autophagy of lipoprotein membranous components of the cytoplasm (Davies 1983). The latter undergo lipid peroxidation and condensation within the lysosomes resulting in the formation of the lipofuscin-rich residual bodies (Brunk \& Collins 1981) Elevated intra-cellular or intra-lysosomal concentrations of metals, such as copper or iron, may contribute to the enhanced lipofuscin content, as these met als are important in mediating the toxic effect of oxygen (Halliwell 1981). Exposure of mussels to $\mathrm{Cu}^{2+}$ results in increased lipofuscin formation in the diges tive cells (Viarengo et al. 1987). In the present field study, the precise role of metals in the pathological alterations associated with lysosomal lipofuscin is unclear, as the levels of metals in the various field samples did not differ greatly (Appendix 1). However in the experimental exposures, copper concentrations in both whole tissues and digestive glands of mussels from the high exposure condition were an order of magnitude greater than in the controls, and this may have contributed to the elevated lipofuscin in these molluscs.

The results provide additional support to the existing evidence for the utility of lysosomally-based indices of cellular and organismal condition, and underline the high sensitivity of tests for lysosomal enlargement and associated fatty degeneration. Such tests are relatively rapid and easy to apply to environmental samples, yet provide considerable insight into the physiological dysfunctions leading to lysosomal pathology. The data showing stimulation of NADPH-ferrihemoprotein reductase activity, linearly related to $\mathrm{PAH}$ concentration, indicate that this component of the cytochrome P-450 system is also a useful indicator of impact by organic xenobiotics, as has been demonstrated on previous occasions (Moore 1985).

Acknowledgement. Microdensitometry was carried out by Sue Farrar and this is gratefully acknowledged.

\section{LITERATURE CITED}

Abdullah, M. I., Steffenak, I. (1988). The GEEP Workshop: trace metal analyses. Mar. Ecol. Prog. Ser. 46: 27-30

Altman, F P. (1972). Quantitatjve dehydrogenase his. tochemistry with special reference to the pentose shunt dehydrogenases. Prog. Histochem. Cytochem. 4: 225-273

Bakke, T., Follum, O. A., Moe, K. A., Sørensen, K. (1988). The GEEP Workshop: mesocosm exposures. Mar Ecol. Prog. Ser. 46: $13-18$

Bancroft, J. D. (1967). An introduction to histochemical technique. Butterworths, London

Bitensky, L., Butcher, R. S., Chayen, J. (1973). Quantitative cytochemistry in the study of lysosomal function In Dingle, J. T (ed.) Lysosomes in biology and pathology, Vol. 3. Elsevier, Amsterdam, p. 465-510

Brunk, U. T., Colluns, V P. (1981). Lysosomes and age pigments in cultured cells. In: Sohal, R. S. (ed.) Age pigments. Elsevier, Amsterdam, p. 243-264

Butcher R. S., Altman, F. P. (1973). Studies on the reduction of tetrazolium salts. II. The measurement of the half-reduced 
and fully reduced farmazans of neotetrazolium chloride in tissue sections. Histochemistry 37: 351-363

Davies, I. (1983). Ageing. Edward Arnold, London

Dianzani, M. U. (1978). Biochemical aspects of fatty liver. In: Slater, T F. (ed.) Biochemical mechanisms of liver injury. Academic Press, London, p. 45-95

Follum, O. A., Moe, K. A. (1988). The GEEP Workshop: field sampling. Mar. Ecol. Prog. Ser 46: 7-12

Halliwell, B. (1981). Free radicals, oxygen toxicity and ageing. In: Sohal, R. S. (ed.) Age pigments. Elsevier, Amsterdam, p. $2-62$

Hawkins, H. K. (1980). Reactions of lysosomes to cell injury. In: Trump, B. F., Arstila, A.V. (eds.) Pathobiology of cell membranes, Vol. 2. Academic Press, New York, p. $252-285$

Klungsøyr, J., Wilhelmsen, S., Westrheim, K., Saetvedt, E., Palmork, K. H. (1988). The GEEP Workshop: organic chemical analyses. Mar. Ecol. Prog. Ser. 46: 19-26

Livingstone, D. R. (1988). Responses of microsomal NADPHcytochrome $c$ reductase activity and cytochrome P.450 in digestive glands of Mytilus edulis and Littorina littorea to environmental and experimental exposure to pollutants. Mar. Ecol. Prog. Ser. 46: 37-43

Livingstone, D. R., Moore, M. N., Lowe, D. M., Nasci, C., Farrar, S. V (1986). Responses of the cytochrome P-450 monooxygenase system to diesel oil in the common mussel, Mytilus edulis L, and the periwinkle Littorina littorea L. Aquat. Toxicol. 7: 79-91

Lowe, D. M., Moore, M. N., Clarke, K. R. (1981). Effects of oil on digestive cells in mussels: quantitative alterations in cellular and lysosomal structure. Aquat. Toxicol. 1. $213-226$

Lüllmann-Rauch, R. (1979). Drug-induced lysosomal storage disorders. In: Dingle, J. T., Jacques, P. J., Shaw, I. H. (eds.) Lysosomes in biology and pathology, Vol. 6. Elsevier, Amsterdam, p. $49-130$

Masters, B. S. S., Okita, R. T (1980). The history, properties and function of NADPH-cytochrome P-450 reductase. Pharmac. Ther. 9: 227-244

Moore, M. N. (1976). Cytochemical demonstration of latency of lysosomal hydrolases in digestive cells of the common mussel. Mytilus edulis, and changes induced by thermal stress. Cell Tissue Res. 175: 279--287

Moore, M. N. (1979). Cellular responses to polycyclic aromatic hydrocarbons and phenobarbital in Mytilus edulis. Mar. environ. Res. 2: 255-263

Moore, M. N. (1985). Cellular responses to pollutants. Mar. Pollut. Bull. 16: 134-139

Moore, M. N., Clarke, K. R. (1982). Use of microstereology and quantitative cytochemistry to determine the effects of crude oil-derived aromatic hydrocarbons on lysosomal structure and function in a marine bivalve mollusc, Mytilus edulis. Histochem. J. 14: 713-718

Moore, M. N., Lowe, D. M., Fieth, P. E. M. (1978). Lysosomal responses to experimentally injected anthracene in the digestive cells of Mytilus edulis. Mar. Biol 48: 297-302

Moore, M. N., Lowe, D. M., Livingstone, D. R., Dixon, D. R. (1986). Molecular and cellular indices of pollutant effects and their use in environmental impact assessment. Wat. Sci. Tech. 18: 223-232

Moore, M. N., Mayernick, J. A., Giam, C. S. (1985). Lysosomal responses to a polynuclear aromatic hydrocarbon in a marine snail: effects of exposure to phenanthrene and recovery. Mar. environ. Res. 17: 230-233

Moore, M. N., Pipe, R. K., Farrar, S. V. (1982). Lysosomal and microsomal responses to environmental factors in Littorina Littorea from Sullom Voe. Mar Pollut. Bull. 13: 340-345

Moore, M. N., Pipe, R. K., Farrar, S. V. (1987). Induction of lysosomal lipid accumulation and fatty degeneration by polycyclic aromatic hydrocarbons in molluscan digestive cells. Mar. environ. Res. (Abstract) 24: 352-353

Moore, M. N., Viarengo, A. (1987). Lysosomal membrane fragility and catabolism of cytosolic proteins: evidence for a direct relationship. Experientia 43: 320-323

Nott, J. A., Moore, M. N. (1987). Effects of polycyclic aromatic hydrocarbons on molluscan lysosomes and endoplasmic reticulum. Histochem. J. 19: 357-368

Owen, G. (1972). Lysosomes, peroxisomes and bivalves. Sci. Prog., Lond. 60: 299-318

Pearse, A. G. E. (1972). Histochemistry, theoretical and applied, Vol. 2. Churchill-Livingstone, London

Pipe, R. K., Moore, M. N. (1985). Ultrastructural changes in the lysosomal-vacuolar system in digestive cells of Mytilus edulis as a response to increased salinity. Mar. Biol. 87: $157-163$

Stebbing, A. R. D. (1981). Hormesis - stimulation of colony growth in Campanularia flexuosa (Hydrozoa) by copper, cadmium and other toxicants. Aquat. Toxicol. 1: 227-238

Storch, J., Kleinfeld, A. M. (1985). The lipid structure of biological membranes. Trends Biochem. Sci. 10: 418-420

Strobel, H. W., Digmann, J. D., Gum, J. R. (1980). NADPHcytochrome $\mathrm{P}-450$ reductase and its role in the mixed function oxidase reaction. Pharmac. Ther. 8: 525-537

Szego, C. M. (1975). Lysosomal function in nucleocytoplasmic communication. In: Dingle, J. T., Dean, R. (eds.) Lysosomes in biology and pathology, Vol. 4. Elsevier, Amsterdam, p. 385-477

Van Noorden, C. J. F., Butcher, R. G. (1986). A quantitative histochemical study of NADPH-ferrihemoprotein reductase activity. Histochem. J. 18: 364-370

Viarengo, A., Moore, M. N., Mancinelli, G., Mazzucotelli, A., Pipe, R. K., Farrar, S. V. (1987). Metallothioneins and lysosomes in metal toxicity and homeostasis in marine mussels: the effects of cadmium in the presence and absence of phenanthrene. Mar. Biol. 94: 251-257

Widdows, J., Johnson, D. (1988). Physiological energetics of Mytilus edulis: Scope for Growth. Mar. Ecol. Prog. Ser. 46: $113-121$ 